\title{
携帯用パワー源のためのマイクロリアクタ Microreactors for Portable Power Sources
}

\author{
○正 田中 秀治（東北大）＼cjkstart張 貴松（東北大院）＼cjkstart佐藤 大祐（東北大院） \\ 吉田 和司（松下電工） 正 江刺 正喜（東北大） \\ Shuji TANAKA ${ }^{1}$, Kuei-Sung CHANG ${ }^{1}$, Daisuke SATO ${ }^{1}$, Kazushi YOSHIDA $^{2}$ and Masayoshi ESASHI ${ }^{1}$ \\ ${ }^{1}$ Tohoku University, 01 Aza Aoba, Aramaki, Aoba-ku, Sendai \\ ${ }^{2}$ Matsushita Electric Works, Ltd., 1048 Kadoma, Osaka
}

\begin{abstract}
The components of a novel miniature fuel cell/fuel reformer system fueled by liquid gases such as butane and propane were prototyped using MEMS technology and tested. In this system, fuel, air and water are supplied to the fuel reformer by utilizing the vapor pressure of the liquid gas for the reduction of power consumption by peripherals and the simplification of the system. The system is composed of a reforming reactor, a catalytic combustor, a polymer electrolyte fuel cell (PEFC), an ejector to supply air to the combustor and other peripherals. The reforming reactor demonstrated the steam reforming of methanol at an equivalent power of $200 \mathrm{~mW}$ and a total efficiency of $6 \%$. The combustor had a stable combustion area above $5 \mathrm{~W}$, and the complete combustion of butane was confirmed by gas chromatography. The ejector showed a potential to supply air required for the complete combustion of butane ( 31 times larger volume than butane).
\end{abstract}

Key Words: Fuel Reformer, Fuel Cell, Portable Power Source, Ejector, Combustor

1.はじめに

液体炭化水素然料は, 現存する最良の電池と比べても, 単位体積・重量当たり大量のエネルギーを有している。た とえば,リチウムイオン電池のエネルギー密度は $200 \mathrm{Wh} / 1$, $100 \mathrm{Wh} / \mathrm{kg}$ 程度であるが，ガソリンのエネルギー密度は 13 $\mathrm{kWh} / \mathrm{l}, 15 \mathrm{kWh} / \mathrm{kg}$ に達する。したがって，仮に数\%の変換 効率で液体炭化水素燃料から発電できれば, 現存のリチウ ムイオン電池のエネルギー密度を凌駕することができる。 また，このような燃料を用いる小形パワー源は, 充電せず に燃料補充するだけで即使用できるという利点を有する。 これは，携帯情報機器をいかなるときにも手放せない人， あるいは工事現場, 災害現場などの充電が難しい場所で用 いられる自立ロボットにとって, 重要な利点である。さら に，リサイクルが困難で，廃㙌されると環境污染の原因に もなりうる電池を，リサイクルの容易な燃料カートリッジ に置き換えられるという利点もある。

このような理由から, 液体炭化水素燃料から電力を生み 出し, 携帯電子機器や移動機械に利用しようとする研究が, 近年, 様々に行われている。研究されている小形パワー源 には, ガスタービン発電機, 燃料電池, 燃料改質器, 熱電 発電器, 熱光発電機などがある。その中で, マイクロ燃料 改質器は PEFC と組み合わせて，ノートパソコンやビデオ カムコーダの電源として用いられると期待されている。マ イク口燃料改質器付き PEFC は, 水素を燃料にする PEFC の出力密度が DMFC のそれより 1 析程度高いことから, シ ステムとしても DMFC より高い出力密度を実現できると 期待されている上, メタノール，エタノール，ブタンなど の種々の燃料を利用できる可能性もある。

\section{2.システム権成}

図 1 にマイクロ燃料電池／燃料改質器システムの構成を 示す。このシステムは, ブタン, プロパンなどの液化ガス の水蒸気改質を行い, PEFCで発電するものであり, PEFC, 燃料改質反応器, 触媒燃焼器, 燃焼器に空気を導入するエ ゼクタなどで構成される。燃料改質反応器には，必要に応 じて, CO を除去するためのシフト反応器やパラジウム水 素分離器が組み合わせられる。
液化ガスを燃料に用いることの利点は，液化ガスの蒸気 圧を有効利用することによって, 燃料や水の供給がポンプ 無しで行えることである。一般的に，マイクロポンプは比 較的消費電力が大きく，しかも，稼動部を有するため信頼 性に不安を残す。また, 然料や水の供給にマイクロポンプ を用いると, 要素の数が増え, システムが複雑になる。我々 が提案する新しいシステムの最大の特徴は, 液化ガスを燃 料に用いることによって，マイクロポンプが不要になるこ とである。

我々のシステムは, メタノールを燃料に用いる従来のマ イクロ燃料改質システムには無い特有の要素開発を必要之 する。具体的には，次のような課題がある。1）液化ガス の水蒸気改質温度は, 数百 ${ }^{\circ} \mathrm{C}$ 以とメタノールのそれ

(300 ${ }^{\circ} \mathrm{C}$ 程度) より高い。効率を上げるためには，反応部 の良好な断熱が必須である。2）液化ガスの水蒸気改質用 の高性能触媒を，それをマイクロリアクタへ固定する方法 と共に開発しなければならない。3）液化ガスを完全燃焼 させるには, 大量の空気が必要である。たとえば, ブタン を完全然焼させるためには,ブタンの 31 倍の体積の空気が 必要である。エゼクタは,このような大量の空気を燃焼器 に導入しなくてはならない。4) 微小領域における液化ガ スの燃焼は, メタノールのそれより難しい。また，マイク 口触媒燃焼器は, 液化ガスを完全然焼できると共に, エゼ クタと組み合わせるために，低圧力損失でなくてはならな い。本研究では, これらの課題を解決するための要素を, MEMS 技術を用いて試作した。

\section{3. マイクロ燃料改筫器 ${ }^{(1)}$}

装置の小形化にともなって，体積当たりの表面積が大き くなることは良く知られている。このスケール効果によっ て，マイクロリアクタでは，加熱・冷却が素早く行えるこ と, 触媒の比表面積が増えることなどの利点が生じるが， 逆に，加熱を必要とする場合，熱逸散が大きくなり，熱効 率が下がるという久点も生じる。マイク口燃料改質器では, 熱効率は最も重要な性能の 1 つであるので, 断熱が必須で ある。我々は，断熱を実現するために，自己支持膜構造を 有するマイクロ燃料改質器を提案している。 
図 2 にマイクロ燃料改質器の構造を示す。自己支持薄膜 の裏表に改質反応器と触媒燃焼器とが形成されている。自 己支持膜上で改質反応・触媒燃焼を行うことによって，反 応部を周囲から断熱し，その熱容量を減らし，さらに両反 忘器間の熱抵抗を下げることができる。自己支持膜の周囲 は酸化シリコン膜で周囲と継っており，中央部は熱伝導率 の高いシリコンの均熱板を有している。この均熱板は, 自 己支持膜上に形成された点火用マイクロヒ一タ兼温度セン サの断線を防ぐ役割を果たしている。

幅 $300 \mu \mathrm{m}$, 長さ約 $7 \mathrm{~mm}$ の流路を $300{ }^{\circ} \mathrm{C}$ に加熱するのに 必要な電力は $0.64 \mathrm{~W}$ と少なく, 流路の 1 本をマイクロヒー タによって $300{ }^{\circ} \mathrm{C}$ 加熱したとき, 流路周囲の基板の温度は おおよそ室温であり，自己支持膜構造による断熱効果が確 認された。このマイクロ燃料改質器を用いて, メタノール の水蒸気改質と水素の自立触媒燃焼とを確認した。メタノ 一ル水溶液（メタノール/水モル比 1) を， $5 \mu \mathrm{l} / \mathrm{min}$ で供給 したとき, 現状では, 改質ガス中の水素の濃度は $24 \%$ と低 く，これはメタノールの転化率にして $19 \%$ に相当する。変 換効率は約 $6 \%$, 水素発生速度は $200 \mathrm{~mW}$ 相当である。

\section{4.マイクロエゼクタ (2)とマイクロ燃焼器 ${ }^{(3)}$}

マイクロエゼクタは図1に示したシステムにおいて，マ イクロポンプを廃するのに必須の要素である。エゼクタは, 一次流体噴流の慣性による負圧と粘性による引きずり効果 とによって，二次流体を吸引する装置であり，バーナの， ズルやチャンバの排気に利用されている。我々のシステム では，一次流体はガス化した液化ガス，二次流体は空気で ある。液化ガスは自らの蒸気圧によって, ノズルから噴出 する。燃料として最も有望なイソブタンは, 室温で 2.5 $\mathrm{kg} / \mathrm{cm}^{2}$ (ゲージ圧) の蒸気圧を有し，完全燃焼には自らの 31 倍の空気を必要とする。

図 3 にマイクロエゼクタの構造を示す。ノズルは超音速 流を作り出すラバルノズル（幅約 $30 \mu \mathrm{m} \times$ 深さ約 $15 \mu \mathrm{m}$ ) である。このマイクロエゼクタを用いて,イソブタンの 31.2 倍の空気を吸入することに成功したが, 空気吸入量は出口 圧力が増えると急激に減少するので, 燃焼器は低圧損でな くてはならない。

マイクロ燃焼器は, シリコン基板に $14 \mathrm{~mm} \times 8 \mathrm{~mm} \times$ 哚さ $0.15 \mathrm{~mm}$ の燃焼室を結晶異方性ウエットエッチングし, そ れにガスポートを形成したパイレックスガラスを陽極接合 しただけの単純な構造である。触媒は白金担持チタニアま たはアルミナであり，ゾルをガスポートから燃焼室に注入 後, 酸化・還元を行って固定した。

このマイクロ燃焼器を用いて，ブタンの自立燃焼を確認 した。ブタンの流量を絞ると, 発熱量を熱逸散量が上回り, 失火するが, 失火時の出力は, ブタンが完全燃焼したとし て, $5 \mathrm{~W}$ に相当する。また, ブタン $4 \mathrm{sccm}$, 当量比 1 の場 合，ガスクロマトグラフィによって排気ガスから CO など の不完全燃焼生成物は確認されなかった。しかし, 赤外線 イメージャによる観察から，高温部がガス入口にできてお り，温度分布を制御することが 1 つの課題である。また， マイクロエゼクタの制約から圧損を数十 $\mathrm{Pa}$ 以下にしなく てはならないが, 現状では, $10 \mathrm{~W}$ の燃焼時にその 1 析大き い压損があり，さらなる低圧損化が必要である。

\section{5. おわりに}

ブタン，プロパンなどの液化ガスを燃料に用いる新しい マイクロ燃料電池/燃料改質器システムを提案した。液化 ガスの蒸気圧を有効利用することによって，空気や水をマ
イクロポンプなしにマイクロ燃料改質器に供給することが 可能になると期待できる。これは, 補機の小電力化, シス テムの単純化に重要である。本研究では, 液化ガスの噴流 を用いて空気を吸入するマイクロエゼクタ，断熱のための 自己支持膜構造を有する燃焼器付きマイクロ燃料改質器, マイクロ燃焼器を試作し，基本動作を確認した。

本研究の一部はNEDOの支援を受けて実施した。

\section{参考文献}

(1) Kuei-Sung Chang et al, 電学論, 123-E, 9 (2003), 346-350.

(2) D. Sato et al., Proc. 20th Sensor Symposium, (2003), 359-364.

(3) K. Yoshida et al., Proc. 20th Sensor Symposium, (2003), 365-370.

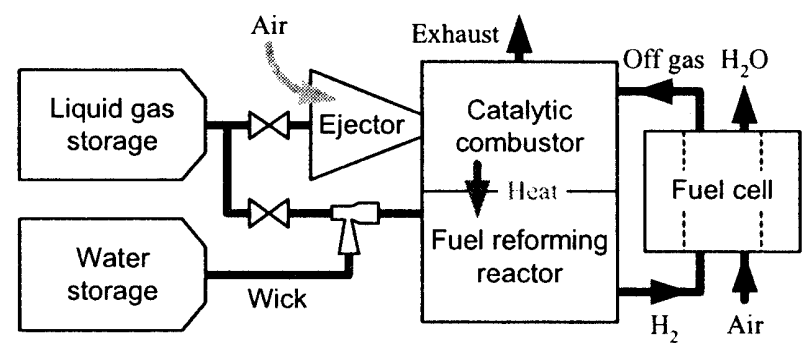

Fig. 1 Configuration of the miniature fuel cell/fuel reformer system

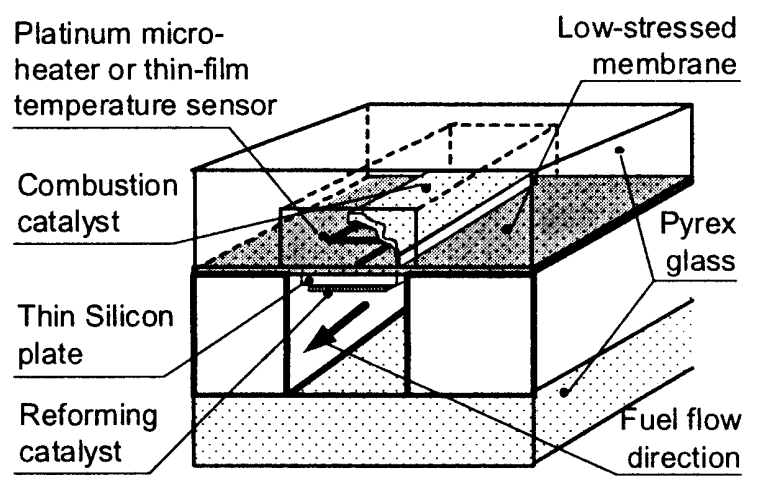

Fig. 2 Structure of the micro-fuel reformer

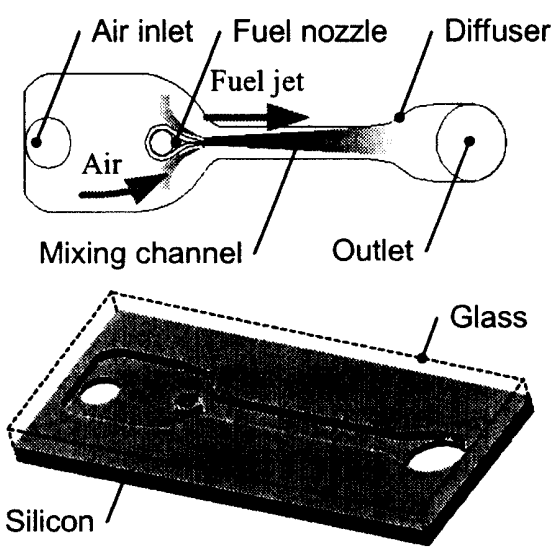

Fig. 3 Structure of the prototyped micro-ejector 